\title{
Implementation Of Teaching English As Local Load In Banda Aceh Elementary School
}

\author{
Halim Majid Raihan Fitria \\ \{halim.majid@gmail.com\} \\ FKIP Universitas Abulyatama Aceh, Indonesia
}

\begin{abstract}
Local load is part of the six year elementary school educational curriculum. It is intended to held the education in the elementary school in term of increasing the quality of the elementary education. English is a part of local load material which has been taught in Banda Aceh elementary schools. This research aims to give a description about the implementation of teaching English as local load in Banda Aceh elementary schools, to convey the problems that are encountered by the teachers and to give the alternative efforts to overcome the teaching English problems. To collect the data, the writer uses the observation and interview. Observation is used to see the teaching and learning English process as local load and interview is used to gain the data about the problem of teaching English in Banda Aceh elementary schools. In analyzing the data, the writer used qualitative analysis. In this case, the result of the data will be described in scientific writing form. Based on the interpretation of the data, it showed that the implementation of teaching English as local load encounters many problems that need to be solved immediately.
\end{abstract}

Keywords: local load, teaching English.

\section{Introduction}

Based on the statement and the principle in the implementation of the government regulation had been determined the new curriculum carrying out the in the elementary education with the Keputusan Depdiknas Nomor 060/U/2010 tanggal 25 Februari 2014 which are conducted since the academic year 2015/2016 gradually. The elementary education curriculum above contains two things. These are national curruculum and the local curriculum. The last one is also called local load. Local load is part of the six year elementary school educational curriculum. It is intended to held the education in the elementary school in term of increasing the quality of the elementary education that suits to the need of the society and environment. In the new curriculum for the elementary school in Indonesia, English becomes one of a local teaching material based on need analyzes. In other words, it can be said that English will be one of the favourite subject depend on the decision-maker of every single school in Indonesia. As the new subject for the teacher of the local load, surely it is quiet difficult to be taught. Slightly it can be seen the problem of the ruling English as one of the local load material. The problem can be found in the process of teaching learning English in the class. For example, from the teachers factor. We can find most of the teachers are not from the teachers of the English department. Thus, they do not understand English well and they sometimes do not know the technique and the methods of teaching English as a foreign 
language. Moreover, they have a lack of knowledge in linguistics aspect such as structure, vocabulary, spelling and pronunciation.

\subsection{Problem Statement}

Specifically, the study attempts to inform the following questions:

1. How is the implementation of teaching English as local load material in Banda Aceh elementary school?

2. What is the problem of teaching English as local load material in Banda Aceh elementary school?

3. How to solve the poblems of teaching English as local load material in Banda Aceh elementary school?

\subsection{Theoretical Framework}

\subsubsection{Teaching English for Elementary School}

Nowadays a number of elementary school put the taching English as the local load subject matter, even in the some cities in Indonesia. English has been introduced in kindergarten. [1] mentioned two main reasons for the conclusion of English language instruction into the elementary school curriculum, they are (1) The growing demand for the English language instruction among the Indoesian's population and (2) The unsatisfactry result of current English instruction.

The purpose of English teahing in Indonesia is both for academic purposes and as a means of international communication. However, it shows that teaching English at elementary school encounters many problems.

According to Bohannon and Leubecker (Latief in Cahyono, 1999:136) there are four approaches in master English. They are behaviouristic approach, linguistic approach, cognitive interaction appproach and social interaction approach.

Behaviouristic approach focuses in learning based on stimulus response correlation. The reinforcement is needed to main role in aquisition of language. According to linguistic approach, children have an independent language structural or language grammatical. Children have a language acquisition device (LAD) as a tool to acquire a language. In cognitive interactions approach a language is an expression of a set of a man cognitive abality in generally. The last approach is social interacion approach. It has an assumption that language development in the result of grammatical acquisition. Environment viewed as an input source of language. In teaching English for elementary school is better to take the good side of every

approaches. For example, the children have to be given English stimulus or reinforcement toward the stimulus. But, they also need to be given chance to communicate and to express their language ability. Giving the chance to use English in interactive and meaningful situation can add the success of teaching English.

In teaching English to the students of elementary school, the activities involved in the classroom must be interesting for the pupils. For this purpose the English teachers play an important role to motivate the students in teaching English.

Rachmayanti (in Cahyono, 1999: 138) stated that there are three techniques to teach English in elementary school. They are (a) through song, (b) through conversation and (c) through game. The third techniques are applied based on some reasons. (1) Using songs in the classroom can grow the students motivation and interest in learning English, and the students can learn pronunciation and structure of language and the vocabulary. By using song the students can immitate and remember language much easier than words with only spoken. The best song for children are the song for singing and for doing action. Philip, (1993:84) stated that song can be used to teach children the sounds and the rhythm of English to reinforce structures and vocabularies and more than that is to have fun. (2) Conversation can have the 
chance to the students to be envolved in the nature situation in a context of their daily life. (3) Game is a pleasure. Most of the people agree that the joy situation can give the motivation to learn well. The other technique that can be applied is storytelling. Based on Dawson (in Cahyono, 1993:139) storytelling can develop the sudents ability in habit to have a full attention. In addition, storytelling can help students to think and develop their idea systematically and can improve their intelegence. The students interest can improve through storytelling. Besides some technique above there are some methods that can be used in teaching language. Depdiknas states that (1996:7) there are communicative method, demonstration or total physical response method, discussion method, experiment method, etc.

The main purpose of using the method is making the students have a skill to use the language. In choosing the appropriate method and technique a teacher should consider some aspects, they are the age of the student, the level of the student ability in learning English, and the situation of the class. Whatever the efforts to improve the teaching ang learning English priocess as local load is needed a creativity by the teacher to develop the strategy, method and technique which innovative anf satisfy the student which is suitable with the field condition. And the one important thing is the teacher must mastered the subject before they teach to the students. (Depdiknas, 1994,15) stated that in the case of the elementary school which carried out English as local load the subject is held by the teacher who has ability and knowledge about the subject itself or by the teacher of English can be provided by the region or by the school itself.

\subsubsection{Method and Technique of Research}

A descriptive approach was used as the research method of this research. Through this method, the teacher described the teaching and learning English process in elementary schools. The direct observation is used to see the teaching and learning English process as local load and interview is used to gain the data about the problems of teaching English from the interpretation and the result of analysis of the data. It can be gained the alternative effort that can be applied in improving teaching English.

\subsubsection{Technique in Analyzing the Data}

Data analysis was a continuous process and also discreetly occurred during data collection. In this research, the writer used the non-statistical analysis of qualitative analysis. It means that the result of the data will be described on scientific writing form.

\section{Meodology}

\subsection{English Teaching Program}

Based on the result of observation and interview, English has been taught in Banda Aceh since the academic year of 1997/1998 gradually from the grade of fourth, fifth to sixth. As the new subject of the local load, it may encounter many difficulties. It has to be solved immediately to make the teaching Engish process can achieve the purpose of learning. In this part we will discuss about the implementation of teaching English in Banda Aceh elementary school, to find the problem that is encountered by the teacher and to find the alternative efforts to solve the problem in teaching and learning English process. Teaching and learning English process is a process that contains interaction beween teacher and students in order to achieve the certain purposes this interaction has some component whose relationship with each others. Those components are teachers, students, materials, and method of instruction, objective, and evaluation. In teaching and learning English process, the teacher has an important role to guide the students in learning, because the teachers are the planners and implementers in 
teaching and learning process. Therefore the teachers have to be professional in their field. She/he must be creative in many things especially about the teaching itself, it must be taught effectively.

Based on the explanation above it is clear that teachers have many responsibilities starting from making a lesson plan about teaching material, performing it, and do an evaluation whether the teaching learning process is sucessful or not. The teachers have to consider the lack of learning source or in other word, what is the material must be taught to the students, how to teach it, and how to measure the result of teaching and learning process that have been done. In addition, the students teaching material, the instruments of teaching and other facilities have important role, too. Eventhough the teachers has creativity in teaching, but it is no supported by the student activity, and lack of student source. It obvious that the learning process cannot achieve good result. Similar to other schools in general, especially in the elementary school, all of the Banda Aceh elementery school, have been doing the teaching and learning process, but in this research the writer has focused in the teaching and learning English process. Further about the implementation of teaching English in Banda Aceh elementary school will be explained below.

\subsection{The Preparation of Teaching}

Before the teachers do the teaching and learning activity, they arrange their activity such as choosing the teaching material, determining method and teaching instrument, and also choosing instrument of evaluation to measure the result of learning that have to be done. All are compounded in one program, namely program satuan pelajaran or lesson plan.

Based on the data, it indicates that only $19 \%$ English teacher made preparation of teaching, while $81 \%$ of others did not make the preparation of teaching. They just follow the curriculum

This case causes the teachers teach mostly without the purpose of teaching. Such as student can recognize vocabulary which are relating to some specific topic, especially the student can mention or translate the words, use the word in simple sentence, pronounce it and write it down. Thus if the teacher did not make preparation of teaching, the teacher do not know the aim of teaching or if they have an aim in their mind they do not know whether they have taught suitable with their aim of teaching. In fact teaching without preparation of teaching can make the time for teaching English does not arrange well. For example, one topic can be taught at one time, but the teacher teach it in two meetings. It makes a number of vocabulary until the end of academic year cannot achieve the target.

\subsection{The Method of Teaching}

Every method has an advantage and disadvantage. Therefore, to determine what proper methods, teachers need to occupy and have to understand many methods of teaching. They are important because method of teaching is the way to convey the teaching material to the students. The method that is used in teaching and learning process must be suitable with the material and the characteristics of the students. Based on the observation, the teachers often use the lecture method. The reason is the English material is more difficult than others are. So, it is needed a clear explanation to make the students more understand. Beside one method above the teacher used the discussion method to make the student active in learning.

\subsection{Teaching and Learning Activity}

In Petunjuk Penerapan Muatan Lokal SD Depdiknas (1999:23-24) it is stated that there are some standards to determine teaching and learning activity such as: (a) The activity must be simple, so consept to be taught is not difficult by the complicted activities. (b) The activity must be related to the daily events and the fact. So, there are connections with the student's life. (c) The activity must envolve the students actively to understand, to 
find and to use the teaching concept. (d) The activity must use ordinary material and instrument that is usualy found in the student's life. (e) The activity must be related to the needs of learning. Based on my research the writer will explain about the activity in teaching and learning in class generally. Those are (a). The teachers prepare the students to receive the material. (b). The teachers give a little bit of explanation about the material that will be taught. (c). The teachers use apperception to ask about the material that will be taught. (d). The teacher explain the material. (e).The teachers give the example about the word in English and the students pay attention tothe teacher.(f). The teacers give question in oral or writing to evaluate the result of teaching.

\section{Result and Discussion}

Grondlund in Joesman (1988:20) stated that evaluation may be defined as a scientific process of determining the event to which international objective are achieved by pupils. So it is important to do an evaluation to know whether the teaching that has been done, successful or not. The result of evaluation will be used by the teacher to dand if the determine the next material. Based on the data there are two forms of evaluation which are used by the teacher. Those are oral and writing forms. In learning activity the teacher often uses oral form to evaluate students achievement after teaching and learning process and if the students are ready for the next material. The reason stated by some of the teacher when the writer interview them it is better to evaluate the student in oral form because in writing form many students cannot answer the question because the difference between the pronuncition and writing form of English. The reason stated by some of the teacher when the writer interview them it is better Based on the explanation above it is clear that the implementation of teaching English as local load in Banda Aceh elementary schools has many problems, which need to solve to make the implementation of teaching English will be achiced in a good result.

As the writer stated in previous chapter that teaching English is a new subject both for the teachers and the students. As a new subject surely there are problems in teaching and leaning process. They are coming from the teachers, students and other factor that have close relation with the teaching itself. Based on the data that found through the observation and interview can be explained the problems, which are found by the teacher in teaching English in Banda Aceh elementary schools.

\subsection{The Problem from the Teachers Factor}

The teacher is one of the ost important fators int eaching and learning process, how the student learning is largerly depends on the teachers. In short, to ensure the good learning achievement require a qualified teacher. In teaching English teacher try to make the students to have the skill of using the language. It is found that in teaching English the teacher has encountered many problems. The first is the teaching background $93 \%$ teachers are not the teachers from the English department. They do not know English well. They do not the technique and the method of teaching English as a foreign language, and also $67 \%$ of them never follow the training so they have lack of knowledge in linguistic aspects such as structure, vocabulary, spelling, and pronunciation. If the teachers do not have ability and knowledge to manage the teaching and learning process the result will be unsatisfactorily. This case hampered in teaching and learing process. For example the teachers find the difficulties to apply the grammar and linguistic rules. Based on my observation it is found that the teachers make many mistakes in pronouncing and grammatical form, and it made the students learning something wrong unware. The next problem that the writer found from the 
teacher's factor fom the text are 79\% teachers in sample school who do not know about the curriculum/GBPP. They teach English directly fro the textbook. It is caused by the teacher and the school did not an attention to a GBPPP and curriculum, so the teacher did not have a guide that can be read and learnt by the teacher to teach English.

\subsection{The Problem from the Student Factor}

As a new subject, also as a new thing for the students it bring about the problem for the student because the environment around them does nt support them to use their language skill. It is meant that learning English is difficult for them. In addition, 625 students in sample school do not have textbook and it makes the techer finf difficult to teach them because they follow the material without understanding the meaning and the objective of teaching are. And of course it wil make their interest to learn English will decrease. They will understand if the teacher uses the words wih have relaton with the thing around them. If the students have textbook it is easy to teach them because in textbook there picture that can help them to recognize and and memorize the words if the words do not present around the school environment, and it can encourage their interest to learn English. Another problem is the larger number of students in the class. They have different characteristic and understanding in learning, so the teacher needs more time to teach them.

\subsection{The Problem from the Teaching Material}

Teaching Englih is more diffifult than teaching Indonesian language because the people who learn a foreign language like English find difficulties to pronunce. These are the English sound. These difficulties come in the form of how to produce the forein sound by the organ of speech and how to produce proper usage in matter of sound articulation such as stress, articulation, pitches, and rhythm. Based on my observation $90 \%$ teachers make mistak in pronouncing Engish sound. For example, the pronunciation of water is pronounced water. Actually the word should be pronounced as $\mathrm{w} \mathrm{t} \mathrm{r}$ and also $60 \%$ teachers make mistake in writing form. For example. There are two cat in the kitchen. It should be there are two cats in the kitchen. Besides the factors above, the lack of teaching english material for elementary school makes the teachers lack of source as standard to teach English. The book which is used $\mathrm{y}$ the teacher is the firts step publish by PT Intanparawira and English for elementary school published by PT Yudistira but it is not enough to fulfill the need of teaching English material because the students must buy to get the book and it is sure that not all the students buy the book. Fraught not suitable with the curriculum or GBPP. For example, the topic colors in GBPP it must be taught at grade fifth that is taught at grade of fourth. And for the grade of sixth there are material which is not put in curriculum and GBPP and not suitable with the students environment. For exampe in sekaten fair in parangtritit beach. Yogyakarta palace, and javanese dance. It is diffificult for the teacher to teach it if the teacher does not know the topic abobe and if the teacher cannot give the fact around the students.

\section{Conclusion}

a. English is as a part of local load has been taught in Banda Aceh elementary school.

b. English is taught for two hours of studying everyweek from the grade of four, fifth to sixth.

c. Teaching English as a ocal load material has many problems. They are: (a).The teachers find many difficulties inlingistic aspects such as structure, voabulary, spelling and pronunciation because the lack of their knowledge about English. (b). $79 \%$ of the 
teachers in sample school do not know about the curriculum and GBPP. They teach English directly from the textbook. And $81 \%$ teachers are teaching without preparation of teaching. (c.) The students find difficulties to learn English because the environment around them does not support them to use their language skill and also $62 \%$ students do not have a textbook that make them difficult to receive the material.(d) The larger number of students in class with different characteristics and understanding in learning make the teacher need more time to teach them. (e). The lack of English teaching material and there is not a book material published by Depdiknas as a guide to the teacher to teach to the students.

\section{Suggestion}

From the explanation above it can be seen that teaching English as local load and i t can be has many problems and it can be seen from the teacher, student and teaching material tself. There are some alternative afforts to solve the problem. They are (1). It is better if the teacher teach by using the preparation of teaching to determine the purpose of teaching, using the method and material of teaching and to make sure that the teacher activity in the class is done to achieve the purpose. (2). The teacher must follow the raining, seminar, etc about English to improve their knowledge in teaching English. (3). It is better if the teacher has the curriculum and GBPP to guide them in teaching English in class. (4). To make the student has an interest and motivation in learning English the teacher must be used the method adaptable with the student's conditions and it is better if he student has a textbook to make them easy to receive the material. (5). To make the teacher easy to teach the students and to achieve a good result in teaching the umber of student in class is not more than 15 stuents (Sadtono, 1995:27).(6). There must a book published by Depdiknas as a teacher guide to English which is relevant with GBPP or curriculum.

\section{References}

[1] N. Huda, "The Teaching of English in Primary School," Issues Probl. English Lang. Teach. Forum, vol. XXV, no. 2, pp. 82-83, 1994. 